\title{
Taming Lust
}




\section{EARLY AMERICAN STUDIES}

\section{Series editors:}

Daniel K. Richter, Kathleen M. Brown,

Max Cavitch, and David Waldstreicher

Exploring neglected aspects of our colonial, revolutionary, and early national history and culture, Early American Studies reinterprets familiar themes and events in fresh ways. Interdisciplinary in character, and with a special emphasis on the period from about 1600 to 1850 , the series is published in partnership with the McNeil Center for Early American Studies.

A complete list of books in the series is available from the publisher. 


\section{TA MING}

\section{LUST}

Crimes Against Nature in the Early Republic

DORON S. BEN-ATAR AND RICHARD D. BROWN

\section{$\overline{\text { PENN }}$}

UNIVERSITY OF PENNSYLVANIA PRESS 
Copyright (C) 2014 University of Pennsylvania Press

All rights reserved. Except for brief quotations used for purposes of review or scholarly citation, none of this book may be reproduced in any form by any means without written permission from the publisher.

\author{
Published by \\ University of Pennsylvania Press \\ Philadelphia, Pennsylvania 19104-4112 \\ www.upenn.edu/pennpress \\ Printed in the United States of America \\ on acid-free paper
}

$\begin{array}{llllllllll}1 & 3 & 5 & 7 & 9 & 10 & 8 & 6 & 4 & 2\end{array}$

Library of Congress Cataloging-in-Publication Data Ben-Atar, Doron S.

Taming lust : crimes against nature in the early Republic /

Doron S. Ben-Atar and Richard D. Brown.-1st ed.

p. cm.- (Early American studies)

Includes bibliographical references and index.

ISBN 978-0-8122-4581-3 (hardcover : alk. paper)

1. Bestiality-United States-Case studies. 2. BestialityUnited States-History-18th century. 3. Criminal justice, Administration of - United States-History-18th century. 4. United States - Civilization-18th century. I. Brown, Richard D.

II. Title. III. Series: Early American studies.

$$
\begin{array}{cc}
\text { HQ71.5.B47B46 } 2014 \\
306.0973-\mathrm{dc23} & 2013033187
\end{array}
$$

